\title{
Conformation-specific Antibodies Targeting Aggregated Forms of $\alpha$-synuclein Block the Propagation of Synucleinopathy
}

\author{
Minsun Choi ${ }^{1 \dagger}$, Tae-kyung Kim ${ }^{1,3 \dagger}$, Jinhyung Ahn', Jun Sung Lee ${ }^{1}$, Byung Chul Jung ${ }^{1}$, Sungwon An ${ }^{2}$, \\ Dongin Kim ${ }^{2}$, Min Jae Lee ${ }^{4}$, Inhee Mook-Jung ${ }^{4}$, Sang Hoon Lee ${ }^{2}$ and Seung-Jae Lee ${ }^{1 *}$ \\ ${ }^{1}$ Department of Biomedical Sciences, Seoul National University College of Medicine, Seoul 03080, ${ }^{2}$ ABL Bio, Inc., Seongnam \\ $13488,{ }^{3}$ Department of Exercise Physiology and Sport Science Institute, Korea National Sport University, Seoul 05541, \\ ${ }^{4}$ Department of Biochemistry and Biomedical Sciences, Seoul National University College of Medicine, Seoul 03080, Korea
}

\begin{abstract}
Abnormal aggregation of $\alpha$-synuclein is a key element in the pathogenesis of several neurodegenerative diseases, including Parkinson's disease (PD), dementia with Lewy bodies, and multiple system atrophy. $\alpha$-synuclein aggregation spreads through various brain regions during the course of disease progression, a propagation that is thought to be mediated by the secretion and subsequent uptake of extracellular $a$-synuclein aggregates between neuronal cells. Thus, aggregated forms of this protein have emerged as promising targets for disease-modifying therapy for PD and related diseases. Here, we generated and characterized conformation-specific antibodies that preferentially recognize aggregated forms of $a$-synuclein. These antibodies promoted phagocytosis of extracellular $\alpha$-synuclein aggregates by microglial cells and interfered with cell-to-cell propagation of a-synuclein. In an $a$-synuclein transgenic model, passive immunization with aggregate-specific antibodies significantly ameliorated pathological phenotypes, reducing $\alpha$-synuclein aggregation, gliosis, inflammation, and neuronal loss. These results suggest that conformation-specific antibodies targeting $\alpha$-synuclein aggregates are promising therapeutic agents for PD and related synucleinopathies.
\end{abstract}

Key words: Parkinson’s disease, Immunotherapy, Synuclein, Microglia

\section{INTRODUCTION}

Parkinson's Disease (PD) is the second-most common agerelated neurodegenerative disease after Alzheimer's disease (AD). Selective loss of dopaminergic neurons in the substantia nigra pars compacta and $a$-synuclein inclusion bodies in the form of Lewy bodies are the pathological hallmarks of PD [1]. Although the cause of PD is unclear, a large body of evidence suggests that misfolding and aggregation of $\alpha$-synuclein in are crucial factors in the pathogenesis of the disease [2]. Synucleinopathies refer to a

Submitted November 1, 2021, Revised January 27, 2022,

Accepted January 27,2022

* To whom correspondence should be addressed.

TEL: 82-2-3668-7037, FAX: 82-2-447-5683

e-mail: sjlee66@snu.ac.kr

These authors contributed equally to this article. group of neurological diseases that are characterized by the presence of $\alpha$-synuclein aggregates in neurons and glia in the brain as a pathological feature. These diseases include PD, dementia with Lewy bodies, and multiple system atrophy.

Post-mortem analyses have suggested that $\alpha$-synuclein aggregation initiated at a few discrete brain regions, such as olfactory bulbs and some brain stem nuclei, spreads through wider brain areas as the disease progresses [3]. The pattern of $a$-synuclein spread correlates with the overall pattern of symptomatic progression, raising the possibility that the former is the underlying mechanism of disease progression [4]. In support of this idea, stereotaxic injection of preformed $a$-synuclein fibrils causes brain-wide spread of a-synuclein aggregates and manifests behavioral and pathological features of neurodegenerative disease in both mice and non-human primates [5-8]. Studies have suggested that direct neuron-toneuron propagation is the mechanism by which aggregates spread through interconnected brain regions [9-11]. 
a-synuclein is a cytosolic protein that is abundant in presynaptic terminals [12]. However, a minor fraction of cellular $\alpha$-synuclein is present in electron-dense vesicles and is released from cells via exocytosis $[13,14]$. This secreted $\alpha$-synuclein adopts both monomeric and aggregated forms. Subsequent studies have shown that extracellular $\alpha$-synuclein aggregates disseminate to neighboring neurons $[15,16]$ and elicit inflammatory responses by glial cells $[17,18]$. In humans, the levels of $\alpha$-synuclein oligomers are elevated in both the plasma and cerebrospinal fluid of PD patients compared with control groups [19-21]. Based on these findings, it has been proposed that extracellular $\alpha$-synuclein aggregates are the culprits that drive disease progression in PD [22]. Targeting these species of a-synuclein may thus be a promising strategy for delaying the progression of PD.

Here, we generated conformation-specific antibodies that preferentially recognize aggregated forms of a-synuclein relative to monomers. We showed that these antibodies promote phagocytosis of $\alpha$-synuclein, thereby enhancing $\alpha$-synuclein clearance from the extracellular space, and block cell-to-cell propagation of a-synuclein. When administered to a transgenic model of synucleinopathy, these antibodies ameliorated pathological phenotypes, reducing $\alpha$-synuclein aggregation, gliosis, inflammation, and neuronal loss.

\section{MATERIALS AND METHODS}

\section{Materials}

The following antibodies were used in this study; $a$-synuclein monoclonal antibody (\#610787, 1:1,500 dilution; BD Biosciences, San Diego, CA, USA), a-synuclein polyclonal antibody (\#2642, 1:1,500 dilution; Cell Signaling Technology; Inc., Danvers, MA, USA), Tau5 (AHB0042, $1 \mu \mathrm{g}$ ml-1; Life Technologies), 6E10 (SIG-39320, $1 \mu \mathrm{g}$ ml-1; BioLegend), phospho-S129 a-synuclein (\#ab59264, 1:500 dilution; Abcam, Waltham, MA, USA), NeuN (\#MAB377, 1:1,000 dilution; Merck Sigma, CA, USA), anti-GFAP (\#ab7260, 1:500 dilution; Abcam), Iba-1 (\#019-19741, 1:200 dilution; Wako, Osaka, Japan), and anti-IL-1 $\beta$ (\#ab9722, 1:200 dilution; Abcam). Isopropyl-1-thio- $\beta$-D-galactopyranoside (IPTG), glycine, thioflavin T (ThT), and protease inhibitor cocktail were purchased from Sigma-Aldrich (St. Louis, MO, USA). HiTrap Q FF anionexchange (\#17-5053-01) and Superdex-200 gel-filtration columns (\#17-5175-01) were purchased from GE Healthcare (Fairfield, CT, USA).

\section{Purification of recombinant a-synuclein}

a-synuclein protein was expressed in Escherichia coli BL21 (DE3) strain (\#RH217; RBC Korea, Seoul, Korea) and was induced by incubating with $0.1 \mathrm{mM}$ IPTG for 3 hours at $37^{\circ} \mathrm{C}$ after the absorbance of the culture medium at $600 \mathrm{~nm}$ (OD600) reached 0.6. Cells were pelleted, resuspended in $20 \mathrm{mM}$ sodium phosphate buffer ( $\mathrm{pH} 7.4$ ), sonicated, boiled at $100^{\circ} \mathrm{C}$ for 20 minutes, and then centrifuged at $10,000 \times \mathrm{g}$ for 10 minutes. $\alpha$-synuclein in the resulting supernatant was purified by anion-exchange chromatography and Superdex-200 gel-filtration column chromatography, then dialyzed against distilled water and lyophilized. For monomer preparation, lyophilized $\alpha$-synuclein was reconstituted in phosphate-buffered saline (PBS; \#CAP08-050; GenDEPOT, Katy, TX, USA), followed by ultrafiltration using a 100,000 MWCO centrifugal device (Pall, NY, USA).

\section{Fibrillation of a-synuclein}

a-synuclein $\left(200 \mu \mathrm{m}\right.$ in PBS) was incubated at $37^{\circ} \mathrm{C}$ for 9 days with constant shaking at 1,050 r.p.m. in a Thermomixer C (\#5382000015, Eppendorf, Hamburg, Germany).

\section{Mutagenesis}

A C-terminal, truncating a-synuclein mutation (1-119) was introduced into human wild-type $\alpha$-synuclein ( $\alpha$-syn/pDualGC) with a QuikChange Site-Directed Mutagenesis Kit (\#200522; Stratagene, La Jolla, CA, USA) using the following primer pair: 5'ATT CTG GAA GAT ATG CCT GTG GAT TAA GAC AAT GAG GCT TAT GAA ATG CC-3' (sense) and 5'-GGC ATT TCA TAA GCC TCA TTG TCT TAA TCC ACA GGC ATA TCT TCC AGA AT-3' (antisense).

\section{Cell culture}

BV-2 microglial cells were maintained in Dulbecco's Modified Eagle Medium (DMEM) containing 10\% fetal bovine serum (FBS) and 100 units ml-1 penicillin and 100 units ml-1 streptomycin at $37^{\circ} \mathrm{C}$ in a humidified 5\% CO2 environment and subcultured every 2 days. For propagation assays, stably transfected V1S and SV2 cells (230,000 cells each) were mixed on a coverslip and cultured for 3 days as described previously [23]. The effects of antibodies on the propagation of $a$-synuclein were assessed by adding antibodies (50 $\mu \mathrm{g} \mathrm{ml-1)}$ to the V1S/SV2 co-culture the day prior to the assay.

\section{Dot blot}

Two-fold serial dilutions (from $50 \mathrm{ng}$ ) of both monomeric (M) and sonicated $\alpha$-synuclein aggregated (A) forms of $\alpha$-synuclein were spotted onto a nitrocellulose membrane. After completely drying, the membranes were wetted with PBS containing 0.05\% Tween-20 (PBST) and blocked with 5\% skim milk in PBST for 30 minutes at room temperature (RT). After a brief rinse, the blots were incubated with antibodies on a shaker at $37^{\circ} \mathrm{C}$ overnight. The 
next day, the membranes were washed three times with PBST, then incubated for 1 hour with horseradish peroxidase (HRP)-conjugated goat anti-mouse antibodies (\#170-6516; Bio-Rad, Hercules, CA, USA), diluted 1:3,000 in PBST containing 5\% skim milk. After washing three times with PBST, the membranes were incubated with ECL solution (\#RPN2232; GE Healthcare). Images were acquired using an Amersham Imager 600 (GE Healthcare) and Multi Gauge (v.3.0) software (Fujifilm, Akishima, Tokyo, Japan).

\section{Sandwich ELISA}

96-Well ELISA plates were coated overnight at $4{ }^{\circ} \mathrm{C}$ with the antibodies, 3A9, 9B11, 11F11 and 11F4 (used as capture antibodies) at $1 \mu \mathrm{g} \mathrm{ml}-1$ in $50 \mathrm{mM}$ carbonate buffer ( $\mathrm{pH}$ 9.6). Plates were washed four times in PBST, after which SuperBlock T20 PBS blocking buffer (\#37516; Thermo Fisher) was added and plates were incubated for 2 hours at RT with modest shaking. Plates were again washed four times in PBST, and samples and standards, freshly prepared by serial dilution of recombinant $\alpha$-synuclein monomer or aggregate solutions, were loaded and incubated at RT for 2.5 hours with modest shaking. Recombinant $\alpha$-synuclein monomers were always filtered through a 100,000 MWCO centrifugal device (UFC510024; Millipore) before use. After washing four times with PBST, $500 \mathrm{ng}$ ml- 1 of biotinylated reporter antibody in binding solution (1\% bovine serum albumen [BSA] in PBST) was added and plates were incubated at RT for 2 hours. The plates were washed four times in PBST, after which avidin-conjugated peroxidase (\#E2886, ExtrAvidin; Sigma-Aldrich) was added at a 1:5,000 dilution in binding solution and plates were incubated for 1 hour at RT. After washing the plates four times with PBST, $100 \mu$ of substrate solution (3, 3,5 ,5'-tetramethylbenzidine [TMB], \#T4444; Sigma-Aldrich) was added to each well and plates were incubated for 10 minutes with shaking in the dark. The reaction was stopped by adding $50 \mu \mathrm{l}$ of $2 \mathrm{~N} \mathrm{H} 2 \mathrm{SO} 4$, and absorbance at $450 \mathrm{~nm}$ was measured using a spectrophotometer (BioTeK, VT, USA).

\section{Uptake of a-synuclein aggregates in cells}

BV-2 microglial cells were split into 35-mm culture dishes on the day before the experiment. $\alpha$-synuclein aggregates $(0.4 \mu \mathrm{M})$, sonicated for the experiment, were pre-incubated with $5 \mu \mathrm{g} \mathrm{ml}-1$ mouse IgG or $\alpha$-synuclein antibodies for 5 minutes at RT. Cells were then washed two times with serum-free media and cultured with pre-incubated complexes for 10 minutes at $37^{\circ} \mathrm{C}$.

\section{Preparation of whole-cell extracts}

Cells were placed on ice, then washed with ice-cold PBS, and lysed in extraction buffer (1\% Triton X-100 and $1 \%[\mathrm{v} / \mathrm{v}]$ protease inhibitor cocktail [Sigma-Aldrich; \#P8465] in PBS). Cell lysates were incubated on ice for 10 minutes and centrifuged at 16,000 $\times \mathrm{g}$ for 10 minutes. The Triton X-100 insoluble fraction (pellet) was resuspended in $1 \mathrm{X}$ Laemmli sample buffer and sonicated briefly.

\section{Dual-cell BiFC cell-to-cell propagation assay}

Cells grown on poly-L-lysine coated coverslips were fixed in PBS containing 4\% paraformaldehyde and permeabilized with PBS containing $0.1 \%$ Triton X-100. Cells were mounted onto slide glasses in the presence of Prolong Gold Antifade Reagent (\#P36931; Invitrogen) and nuclei were stained with TOPRO-3 iodide (\#T3605; Invitrogen). An InCell 2200 Analyzer (GE Healthcare; USA) was used for image analysis. Twenty regions $(\sim 1,500$ cells/region) were randomly selected from each slide.

\section{Western blotting}

Western blotting was performed as described previously [24]. Images were obtained and quantified using an Amersham Imager 600 (GE Healthcare) and Multi Gauge (v3.0) software (Fujifilm).

\section{Animal model and passive immunization}

A Tg mouse model overexpressing full-length human a-synuclein under control of the murine Thyl promoter (mThy1a-syn Tg, Line61) and wild-type littermates were used for this study [25]. A total of 36 --synuclein Tg and 6 non-Tg mice, all 3 months old and male, were used. Mice were intraperitoneally injected weekly with antibodies (10 mg kg-1) for 3 months ( $\mathrm{n}=5 \sim 6$ mice per group) and analyzed at the end of the immunization protocol. Brains and peripheral tissues were removed, and brain hemispheres were divided sagittally. The right hemibrains were post-fixed in phosphate-buffered $4 \%$ paraformaldehyde at $4{ }^{\circ} \mathrm{C}$ for immunohistochemistry analysis. All animals were housed under a 12-hour light dark cycle and had free access to food and water. Animal housing and treatment and tissue preparation were performed at the University of California San Diego (UCSD) under the outsourcing contract. All experiments described were approved by the animal subjects committee at the UCSD and were performed according to the National Institutes of Health Guide for the Care and Use of Laboratory Animals.

\section{Immunohistochemistry}

Immunohistochemical staining was performed as described previously [26]. Briefly, post-fixed brains were coronally cut into $40-\mu \mathrm{m}$-thick sections with a vibratome (Leica VT 1000S; Leica Instruments, Nussloch, Germany). Floating sections were blocked by incubating with $4 \%$ BSA in PBS containing $0.1 \%$ Triton X-100 for 1 hour, then incubated overnight at $4{ }^{\circ} \mathrm{C}$ with primary antibodies. Sections were washed with PBS containing 0.1\% Triton X-100, 
then incubated with secondary antibodies diluted 1:200 in PBS containing $0.1 \%$ Triton X-100. Signals were visualized using an ABC Elite kit (PK-6200; Vector Laboratories, Burlingame, CA, USA). Immunoreactivity was quantified by analyzing images of DAB-stained sections using a bright field digital ZEISS AX-10 microscope and the Image J program (NIH).

\section{Statistical analysis}

Values shown in figures represent means \pm s.e.m. Statistical significance was determined by calculating $\mathrm{p}$-values using paired, twotailed Student's t-tests and one-way analysis of variance (ANOVA) with Tukey's post-hoc test using GraphPad Prism 7.04 (GraphPad Software Inc., La Jolla, CA, USA). Graphs were drawn using GraphPad Prism 7.04.

\section{RESULTS}

\section{Generation of conformation-specific a-synuclein antibodies}

To generate conformation-specific antibodies against $\alpha$-synuclein aggregates, we immunized C57BL6 mice with fibrils generated from either C-terminally truncated or full-length $a$-synuclein (Fig. 1A). Both these fibrils exhibited typical amyloid fibril morphologies (Fig. 1B). These immunizations yielded 13 clones. Antibody isotype analysis showed that the antibodies generated were $\operatorname{IgG} 1$, IgG2a, IgG2b, or IgG3 (Fig. 1C). To evaluate the specificity of the antibodies for $\alpha$-synuclein aggregates, we performed dot blot analyses, spotting two-fold serial dilutions (from $50 \mathrm{ng}$ ) of both monomeric (M) and fibril (F) forms of $\alpha$-synuclein onto a nitrocellulose membrane. These analyses showed that 4 out of 13 antibodies exhibited strong selectivity for aggregated forms of $\alpha$-synuclein (Fig. $1 \mathrm{D}, 1 \mathrm{E})$. Of these antibodies, three-3A9, 9B11 and 11F11-were selected for follow-up study based on their stability, solubility, and binding specificity towards $\alpha$-synuclein aggregates. Unlike these three antibodies, clone 11F4 recognized both monomeric and fibril forms of $a$-synuclein (Fig. 1D, 1E), and was chosen for comparison with the three aggregate-specific antibodies. In this paper, we refer to $11 \mathrm{~F} 4$ as pan- $\alpha$-synuclein antibody, which indicate the antibody that recognize $\alpha$-synuclein regardless of conformation of the protein, hence recognizing both monomers and various forms of multimers including fibrils. To confirm the specificity of antibodies towards aggregates, we performed sandwich enzymelinked immunosorbent assays (ELISAs), detecting serially diluted recombinant human $\alpha$-synuclein proteins using biotinylated-7B7 as a detection antibody and each indicated antibody as a capture antibody. Whereas 11F4 detected both a-synuclein monomers and aggregates, 3A9, 9B11 and 11F11 preferentially recognized $\alpha$-synuclein aggregates compared with the monomer (Fig. 1F).
Next, we investigated their cross-reactivity with other protein aggregates related to neurodegenerative diseases, spotting monomeric and fibrillar forms of $\alpha$-synuclein, tau, and amyloid $\beta$ on the membrane. As shown in Fig. 1G, none of the three conformationspecific antibodies cross-reacted with tau or amyloid $\beta$.

\section{Conformation-specific antibodies enhance clearance of extracellular a-synuclein aggregates and block cell-to-cell propagation}

In our previous study, we showed that extracellular $\alpha$-synuclein aggregates can be internalized and degraded by lysosomes, and further demonstrated that microglia are the cell type most efficient in clearing extracellular $\alpha$-synuclein $[27,28]$. As shown in Fig. 2A, our previous study also showed that treatment with antibodies against $\alpha$-synuclein enhanced uptake of extracellular $\alpha$-synuclein in BV-2 microglial cells (Fig. 2A) [29]. To examine the effects of conformation-specific antibodies on the uptake of extracellular $\alpha$-synuclein aggregates in microglial cells, we preincubated $\alpha$-synuclein fibrils $(0.4 \mu \mathrm{M})$ with either $5 \mu \mathrm{g}$ ml- 1 of control IgG or antibodies against $\alpha$-synuclein for 5 minutes at room temperature and then treated BV-2 cells with $\alpha$-synuclein fibril antibody solution for 10 minutes at $37^{\circ} \mathrm{C}$. Of the three conformationspecific antibodies isolated, 9B11 significantly increased uptake of extracellular a-synuclein fibrils in BV-2 cells (Fig. 2B, 2C). To rule out the measurement of cell surface-attached $\alpha$-synuclein, we washed the cells with an acidic solution to remove the cell surfacebound $\alpha$-synuclein fibrils and analyzed the image with confocal microscopy. The findings were consistent with those obtained from western blotting (Fig. 2B, 2C). The results showed that 9B11 significantly increased the levels of the internalized $\alpha$-synuclein fibrils (Fig. 2D, 2E).

Antibodies can also interfere with cell-to-cell propagation of $\alpha$-synuclein aggregates $[23,30]$. To evaluate the ability of antibodies to block this propagation, we used the dual-cell BiFC propagation assay system developed in our previous study [23]. The dual-cell BiFC system, composed of two cell lines, V1S and SV2, allows $\alpha$-synuclein propagation between these cell types to be monitored by the appearance of fluorescent spots. When added to this propagation-assay system, all antibodies tested significantly reduced the number of BiFC-positive cells (Fig. 2F, 2G), indicating that conformation-specific antibodies effectively inhibit cell-tocell propagation of $\alpha$-synuclein.

\section{Passive immunization with aggregate-specific antibodies reduces a-synuclein deposition, neurodegeneration, gliosis, and inflammation}

To examine the effects of the aggregate-specific antibodies, 3A9, 
A

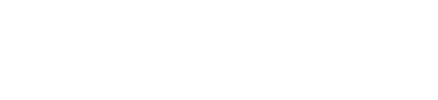

WT a-synuclein

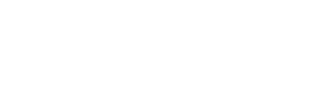

C-terminal truncated $\alpha$-synuclein

B

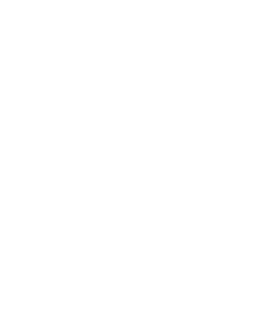

WT a-synuclein

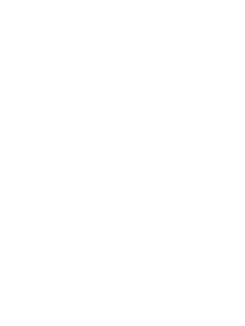

C-terminal truncated a-synuclein
C

\begin{tabular}{|c|c|c|}
\hline Clone name & Antigen for immunization & Isotype \\
\hline $1 \mathrm{E} 4$ & Full-length $\alpha$-syn fibril & $\operatorname{lgG1}$ \\
\hline $1 \mathrm{H} 8$ & C-terminal truncated a-syn fibril & $\operatorname{lgG1}$ \\
\hline $2 \mathrm{E} 3$ & C-terminal truncated a-syn fibril & $\lg G 2 a$ \\
\hline $3 \mathrm{~A} 9$ & C-terminal truncated a-syn fibril & $\lg G 2 b$ \\
\hline 3D3 & C-terminal truncated a-syn fibril & $\operatorname{lgG} 2 a$ \\
\hline $4 \mathrm{G} 3$ & C-terminal truncated a-syn fibril & $\operatorname{lgG1}$ \\
\hline $5 \mathrm{~A} 7$ & Full-length a-syn fibril & $\operatorname{lgG1}$ \\
\hline $6 \mathrm{~F} 7$ & C-terminal truncated a-syn fibril & $\operatorname{lgG} 1$ \\
\hline 7B7 & C-terminal truncated a-syn fibril & $\lg G 2 b$ \\
\hline 9B11 & Full-length a-syn fibril & $\operatorname{lgG} 3$ \\
\hline $10 \mathrm{~F} 10$ & C-terminal truncated a-syn fibril & $\lg G 2 a$ \\
\hline $11 \mathrm{~F} 4$ & Full-length a-syn fibril & $\lg G 2 a$ \\
\hline $11 \mathrm{~F} 11$ & C-terminal truncated a-syn fibril & $\lg G 2 b$ \\
\hline
\end{tabular}
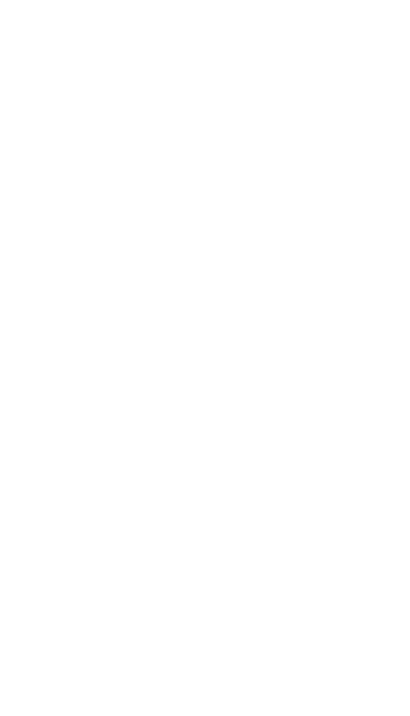

$E$

F

\begin{tabular}{c|c} 
& \\
Clone name & Preference \\
\hline $1 \mathrm{E} 4$ & $\mathrm{M}<<\mathrm{F}$ \\
\hline $1 \mathrm{H} 8$ & $\mathrm{M}<<\mathrm{F}$ \\
\hline $2 \mathrm{E} 3$ & $\mathrm{M}<<<\mathrm{F}$ \\
\hline $3 \mathrm{~A} 9$ & $\mathrm{M}<<\mathrm{F}$ \\
\hline $3 \mathrm{D} 3$ & $\mathrm{M}<\mathrm{F}$ \\
\hline $4 \mathrm{G} 3$ & $\mathrm{M}<<\mathrm{F}$ \\
\hline $5 \mathrm{~A} 7$ & $\mathrm{M}<\mathrm{F}$ \\
\hline $6 \mathrm{~F} 7$ & $\mathrm{M}<\mathrm{F}$ \\
\hline $7 \mathrm{~B} 7$ & $\mathrm{M}=\mathrm{F}$ \\
\hline $9 \mathrm{~B} 11$ & $\mathrm{M}<<<\mathrm{F}$ \\
\hline $10 \mathrm{~F} 10$ & $\mathrm{M}<\mathrm{F}$ \\
\hline $11 \mathrm{~F} 4$ & $\mathrm{M}<\mathrm{F}$ \\
\hline $11 \mathrm{~F} 11$ & $\mathrm{M}<<<\mathrm{F}$ \\
\hline &
\end{tabular}
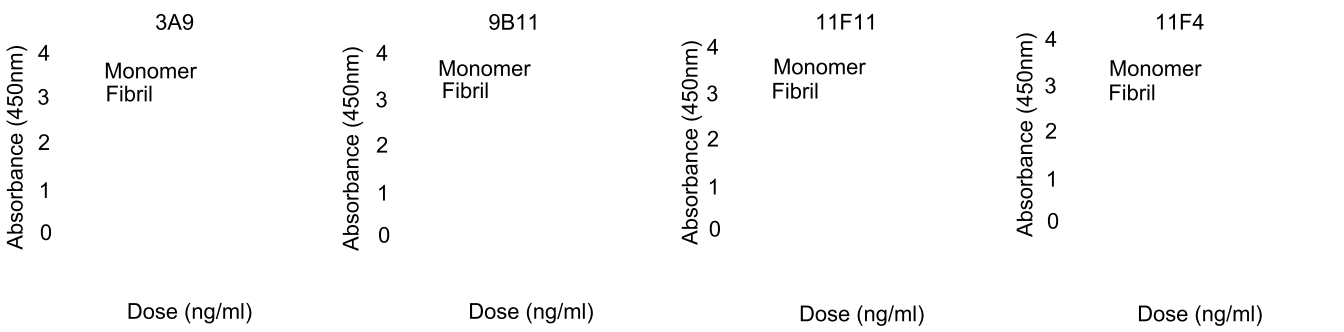

G
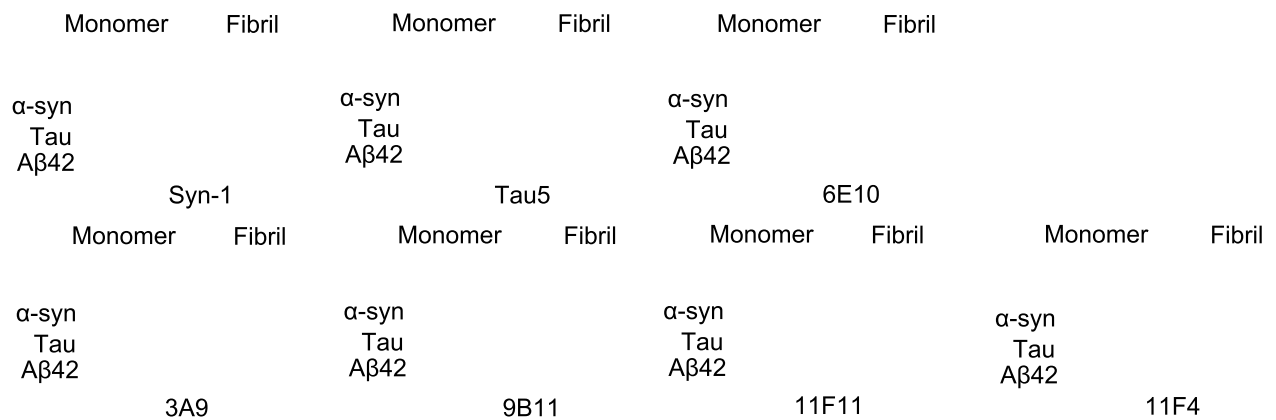

Fig. 1. Characterization of a-synuclein antibodies. (A) Antigens for immunization for production of antibodies. (B) Ultrastructural image of the proteins in (A). (C) Information on immunogens and isotypes of resulting antibody clones. Conformation-specific antibodies were generated by immunization of C57BL6 mice with either full-length $\alpha$-synuclein or C-terminally truncated $\alpha$-synuclein. (D) Specificity for monomer (M) or fibril (F) in dot blots. (E) Preference for aggregated forms of $a$-synuclein based on (D). The relative affinity towards $\mathrm{M}$ and $\mathrm{F}$ forms is indicated by the number of ${ }^{\prime}<$ ' symbols. "M $2<<F$ " antibodies were selected for further assay. (F) Affinity of antibodies for monomer and aggregated forms of $\alpha$-synuclein, determined by sandwich ELISA. (G) Cross-reactivity with amyloid $\beta 42$ and tau proteins. Two-fold serial dilutions (from 50 ng) of both monomeric and aggregated proteins were spotted onto a nitrocellulose membrane. Syn-1, Tau 5 and $6 \mathrm{E} 10$ antibodies were used as positive controls for $\alpha$-synuclein, tau, and amyloid $\beta 42$ respectively. 
B
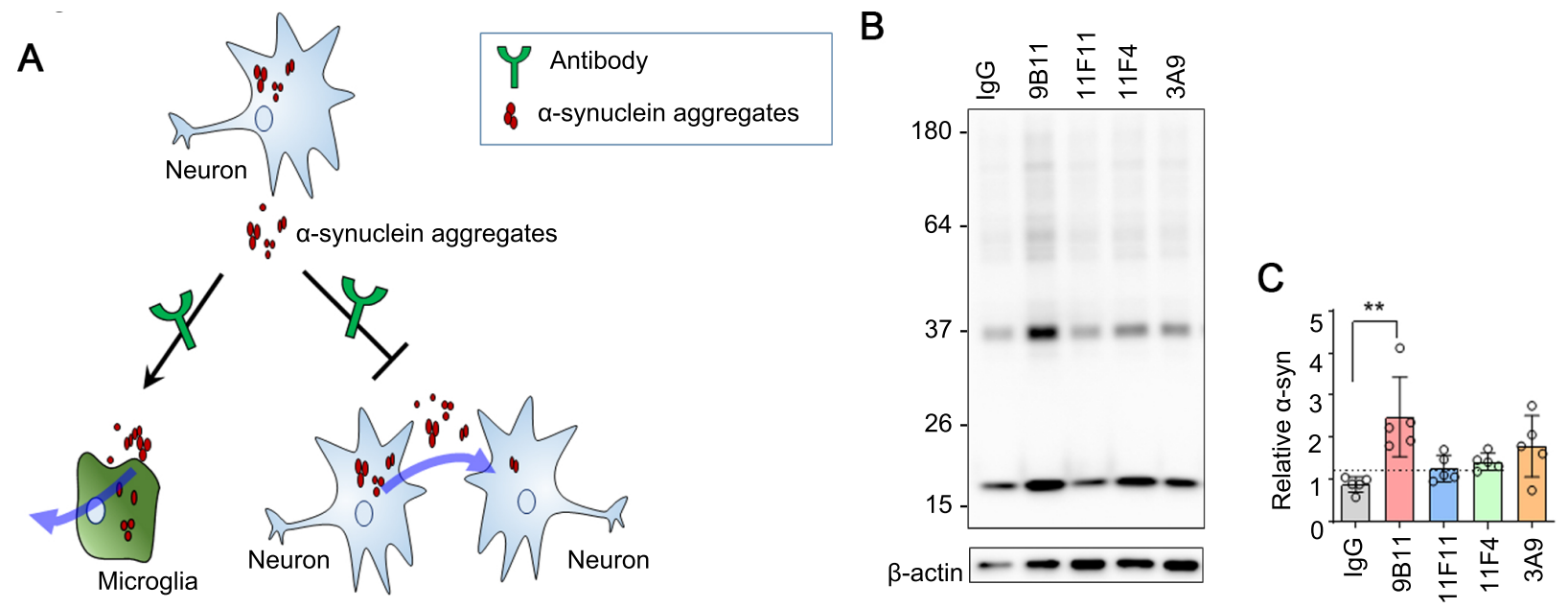

$\mathrm{D}$
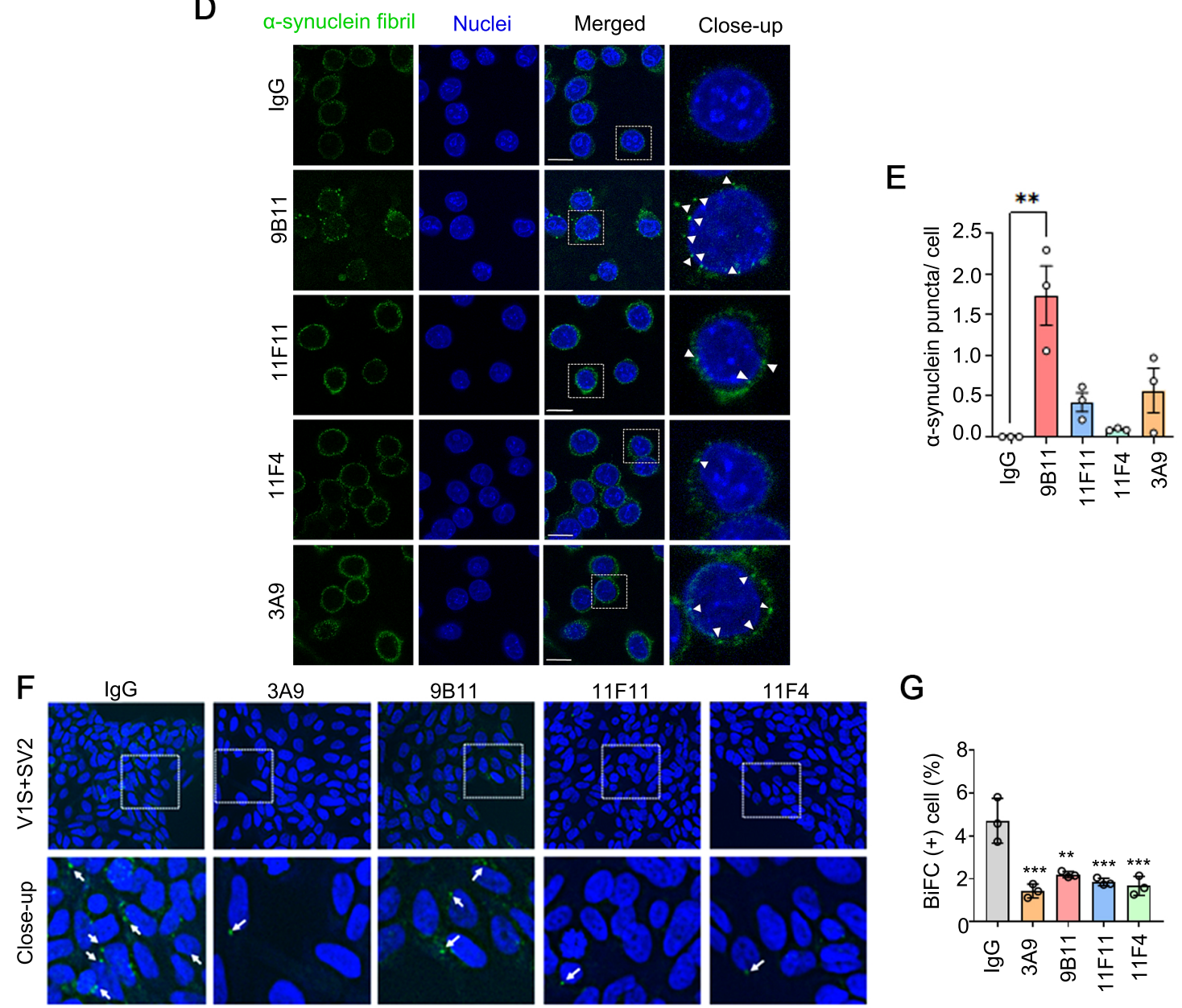

G

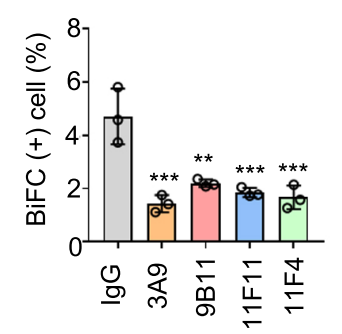

Fig. 2. Conformation-specific antibodies enhance the clearance of extracellular $a$-synuclein aggregates in BV-2 cells and block cell-to-cell propagation. (A) Proposed mechanism of action of antibodies in the uptake of extracellular $\alpha$-synuclein and cell-to-cell propagation. (B) Internalization of a-synuclein fibrils in the presence of the indicated antibodies in BV-2 microglial cells. (C) Amount of internalized $\alpha$-synuclein, quantified and normalized to the levels of $\beta$-actin. (D) Immnofluorescence images of $\alpha$-synuclein fibrils in BV-2 cell after acid wash. Nuclei was stained by DAPI. The closeup panel: Magnified images of the boxed area. Scale bars: $20 \mu \mathrm{m}$. (E) Fluorescence puncta from the internalized $\alpha$-synuclein fibril in (D) were quantified. Puncta was indicated with white arrowheads. One hundred cells per each coverslip were analyzed from three independent experiments. (F) Blocking effects of antibodies against the propagation of a-synuclein. BiFC-positive inclusions are indicated with white arrowheads. Bottom panels: Magnified images of the boxed area. Images were acquired with an InCell analyzer 2200. (G) Quantification of BiFC-positive cells in (F). All data are expressed as means \pm s.e.m. ( $\mathrm{n}>10,000$ cells per experiment (three independent experiments were performed); one-way ANOVA with two-sided Tukey's post hoc test). 
$9 \mathrm{~B} 11$ and 11F11, together with those of the pan- $\alpha$-synuclein antibody, $11 \mathrm{~F} 4$, on the accumulation of $\alpha$-synuclein in vivo, we administered these antibodies intraperitoneally into $\alpha$-synuclein transgenic (Tg) mice, and performed immunohistochemical analyses using antibodies against phosphorylated $\alpha$-synuclein (pS129) and total $\alpha$-synuclein (Fig. 3). Passive immunization with each of the above antibodies significantly reduced pS129 $\alpha$-synuclein levels in the parietal cortex of $\alpha$-synuclein Tg animals (Fig. 3A, 3C). A trend towards reduced pS129 was observed in the prefrontal cortex of antibody-treated animals, although this difference did not reach statistical significance (Fig. 3B). Similar trends were also observed in the hippocampus, with $11 \mathrm{~F} 11$ producing a significant decrease in pS129 levels in the CA1 region, and 11F4 and 3A9 producing significant decreases in the CA3 region (Fig. 3D, 3E). Immunohistochemical analyses of total $\alpha$-synuclein showed reductions in a-synuclein deposition in the prefrontal cortex, parietal cortex, and $C A 1$ and $C A 3$ regions of the hippocampus (Fig. 3G 3J). In the case of total $\alpha$-synuclein, 9B11,11F11 and 11F4 antibodies were more effective in reducing $\alpha$-synuclein deposition than the $3 \mathrm{~A} 9$ antibody (Fig. 3G 3J). To verify these immunohistochemical data, we have performed western analysis with the brain extracts and found that although only the 11F11 showed statistically significant effect, all the antibodies exhibited trends toward reducing the levels of the total $\alpha$-synuclein (Fig. 3K, 3L). To determine the levels of fibril forms of $\alpha$-synuclein in the brain extracts, we also performed dot blot analysis with the FILA-4 antibody, an antibody specific for fibrillar $\alpha$-synuclein [31]. Again, the levels of $\alpha$-synuclein fibrils in the brain extracts were consistently reduced with the conformation-specific antibody treatments, although only the 3A9-treated group reached the statistical significance (Fig, $3 \mathrm{M}, 3 \mathrm{~N}$ ).

We then examined the effects of these antibodies on neurodegeneration, gliosis, and inflammation. The Tg model used in this study showed neuronal loss in the hippocampus CA1 region (Fig. 4A, 4C) as also reported previously [32]. Treatment with a-synuclein antibodies prevented neuronal loss, as assessed using the NeuN antibody, with 11F11 and 11F4 being more effective than the other two antibodies (Fig. 4A, 4C). Next, we examined astrogliosis and microgliosis in the prefrontal cortex, parietal cortex, and hippocampus. Immunohistochemical analyses using an antibody against glial fibrillary acidic protein (GFAP) showed reductions in astroglial cells in both the parietal cortex and the hippocampus in Tg mice treated with a-synuclein antibodies compared with those treated with control IgG antibodies (Fig. $4 \mathrm{D} 4 \mathrm{~F}$ ). Likewise, immunohistochemical analyses using an antibody against Ibal (ionized calcium binding adaptor molecule 1) showed reduced microglial cell numbers in the same brain regions in antibody-treated animals compared with IgG control-treated animals (Fig. 4G 4I). The effects on microgliosis were more pronounced in the prefrontal cortex than in the hippocampus. Finally, we examined brain inflammation by measuring levels of the proinflammatory cytokine, IL-1 $1 \beta$, in the hippocampus. IL-1 $\beta$ levels in $\mathrm{Tg}$ mice treated with antibodies were significantly reduced compared with those in mice treated with control IgG (Fig. 4J, 4K).

\section{DISCUSSION}

In this work, we generated $\alpha$-synuclein antibodies by immunization of C57BL6 mice with either full-length or C-terminally truncated $\alpha$-synuclein fibrils. Of the 13 antibodies generated, four $(2 \mathrm{E} 3,3 \mathrm{~A} 9,9 \mathrm{~B} 11$ and $11 \mathrm{~F} 11)$ were determined to be specific to the fibril forms of $\alpha$-synuclein. Among these antibodies, we selected three (3A9, 9B11 and 11F11) for further characterization. None of these three antibodies cross-reacted with monomeric $\alpha$-synuclein, nor did they react with other neurodegenerative disease-related proteins (i.e., amyloid $\beta 42$ and tau). Notably, all of these conformation-specific antibodies effectively blocked the propagation of a-synuclein aggregates between neuronal cells. In addition, 9B11 enhanced the uptake of $\alpha$-synuclein fibrils in BV-2 microglial cells, underscoring the ability of this antibody to enhance clearance of extracellular $\alpha$-synuclein aggregates. Furthermore, passive immunization with each conformation-specific antibody ameliorated neuropathological features of $\alpha$-synucleinopathy in a Tg mouse model, reducing $\alpha$-synuclein aggregates, gliosis, inflammation and neuronal loss. These results suggest that, by virtue of their ability to effectively neutralize the pathogenic functions of $\alpha$-synuclein aggregates, the conformation-specific antibodies developed here have potential for use as therapeutic agents.

Two mechanisms have been proposed to explain how immunotherapy against $a$-synuclein works. First, antibodies block the cell-to-cell propagation of $\alpha$-synuclein by capturing extracellular a-synuclein secreted from neurons $[23,30]$. Second, antibodies aid the clearance of extracellular $\alpha$-synuclein by promoting uptake and degradation of the protein by microglia [29]. This latter mechanism is mediated by $\mathrm{F} c \gamma$ receptors, which recognize a-synuclein -antibody complexes; $F c \gamma$-mediated uptake appears to result in faster delivery of cargoes to lysosomes than occurs with the normal $\alpha$-synuclein uptake pathway [29]. In the current study, we showed that at least one conformation specific antibody, 9B11, significantly increased the clearance of extracellular $\alpha$-synuclein fibrils by microglial cells. The antibodies may influence in the microglial degradation of $\alpha$-synuclein fibrils in addition to the uptake. In our previous study [29], we have shown that $\alpha$-synuclein antibodies indeed accelerated the intracellular trafficking of the internalized fibrils to lysosomes. The clearance rate is determined 
A

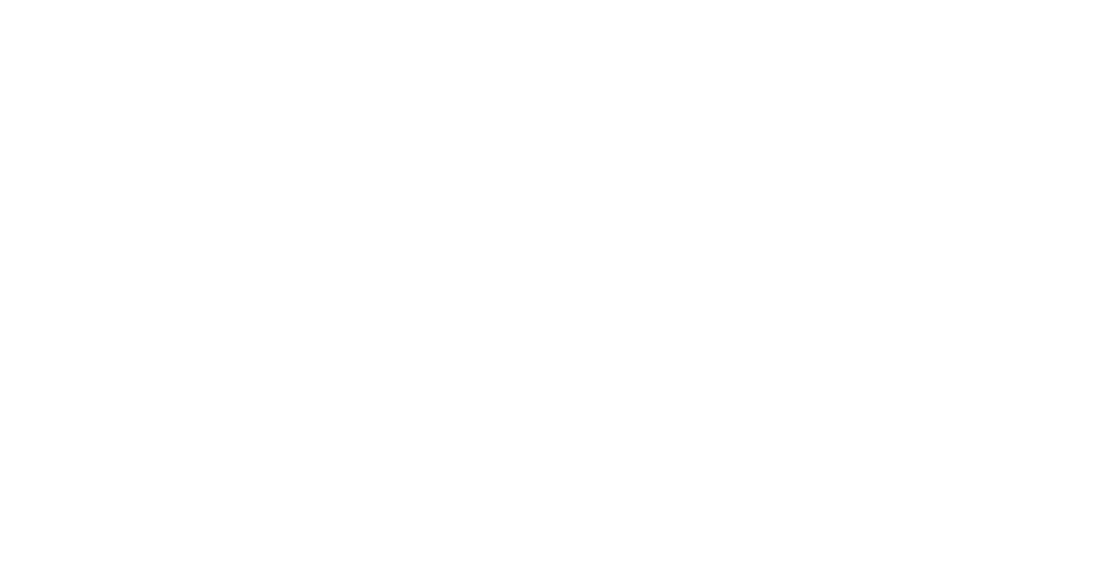

$\mathrm{F}$
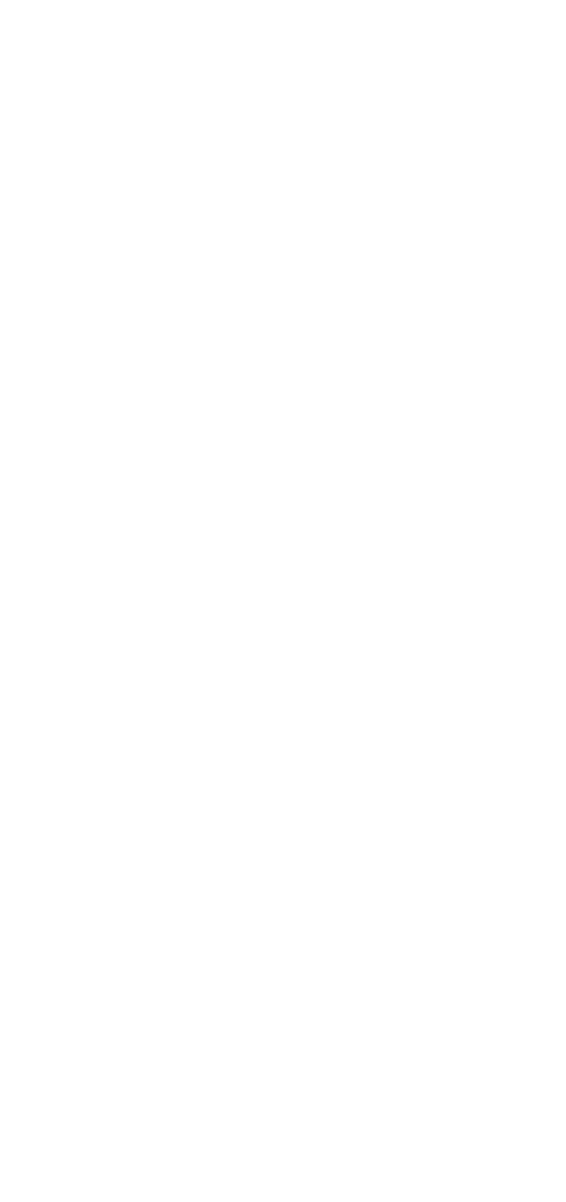

L
B
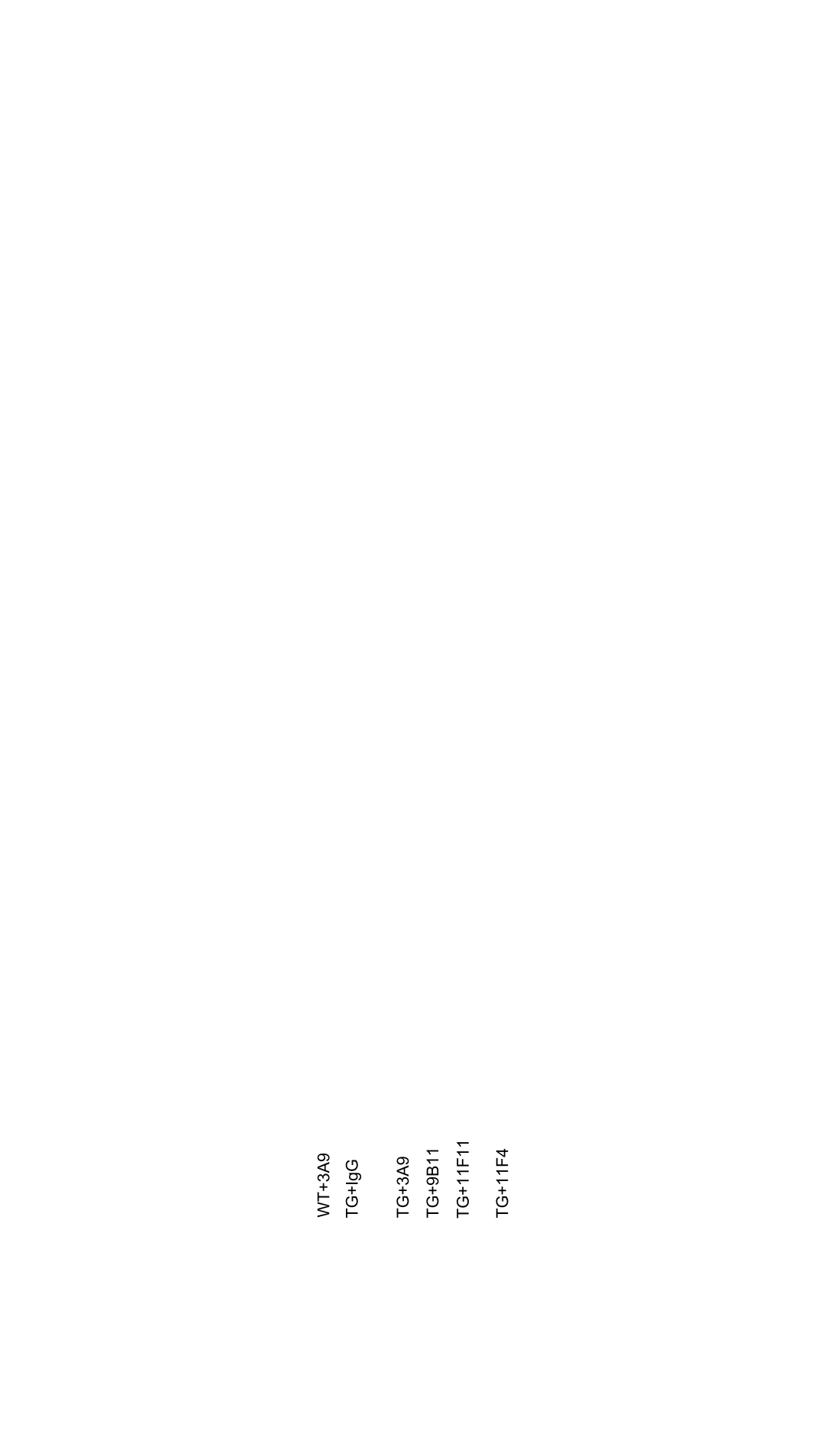

M

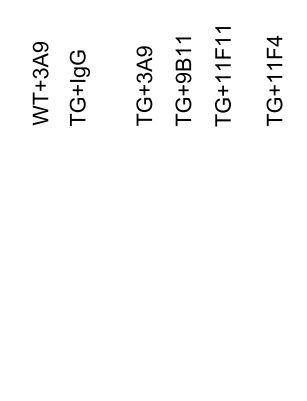

$\mathbf{N}$

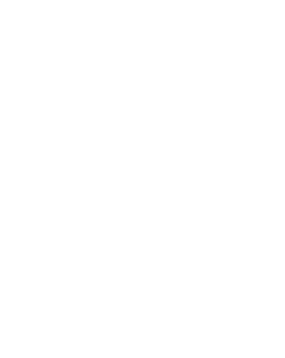

Fig. 3. Passive immunization reduces $\alpha$-synuclein deposition in mThy-1- $\alpha$-synuclein Tg mice. mThy-1- $\alpha$-syn Tg mice and non-Tg littermates were injected with aggregate-specific antibodies and a pan- $\alpha$-synuclein antibody (10 mg kg-1, i.p.) weekly for 3 months. (A) Representative images of phosphorylated $\alpha$-synuclein (pS129) staining in the prefrontal cortex, parietal cortex, and hippocampal regions. (B E) Optical density measurements in the prefrontal cortex (B), parietal cortex (C), and hippocampal regions (D, E). (F) Representative images of total- $\alpha$-synuclein staining in the prefrontal cortex, parietal cortex, and hippocampal regions. (G J) Optical density measurements in the prefrontal cortex $(\mathrm{G})$, parietal cortex (H), and hippocampal regions (I, J). Scale bar, $200 \mu \mathrm{m}$, Data are expressed as means \pm s.e.m. ( $\mathrm{n}=5 \sim 6$ per group; $\# \mathrm{p}<0.05$ vs. WT $+3 \mathrm{~A} 9$ group, ${ }^{*} \mathrm{p}<0.05 \mathrm{vs}$. TG $+\mathrm{IgG}$ group; one-way ANOVA with two-sided Tukey's post hoc test). Pfcx, prefrontal cortex; Pacx, parietal cortex; HP, hippocampus. (K L) Western blotting of brain tissue extracts. (M N) Dot blotting of brain tissue extracts. FILA-4 antibody, an antibody specific for fibrillary a-synuclein were used. Data were analyzed by one-way ANOVA with two-sided Tukey's post hoc test. ${ }^{*} \mathrm{p}<0.05^{* * * *} \mathrm{p}<0.0001$ vs. TG+IgG group. 
A

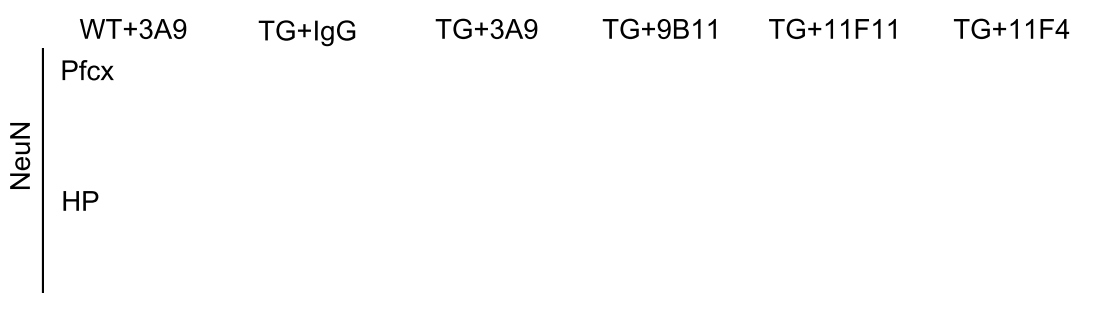

B

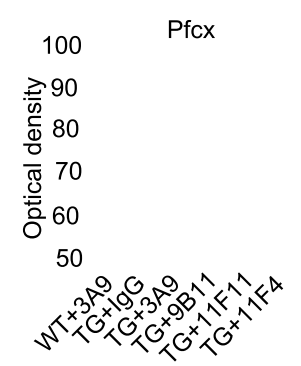

$\mathrm{E}$
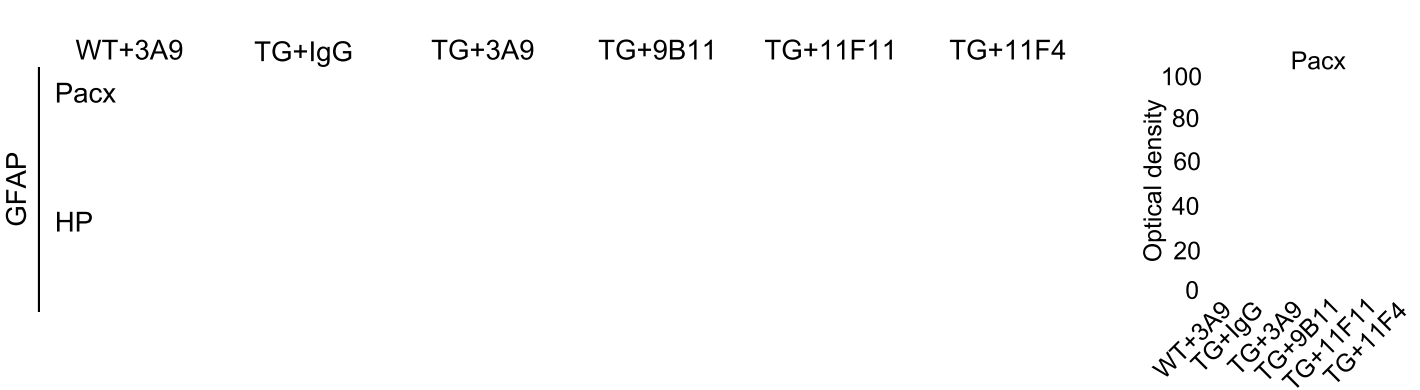

$\mathrm{F}$

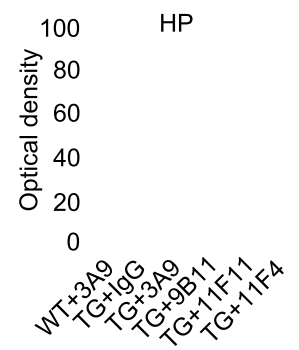

$\mathrm{H}$
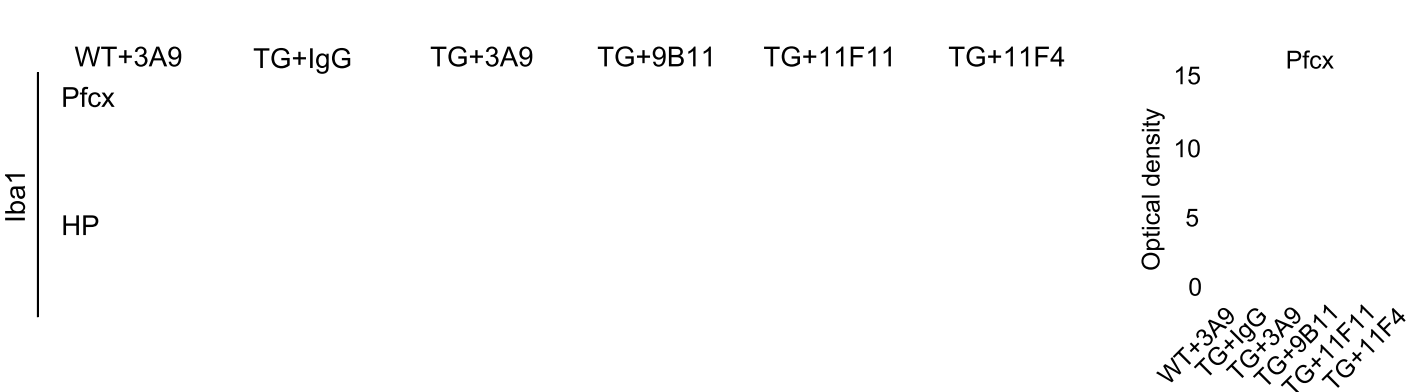

I

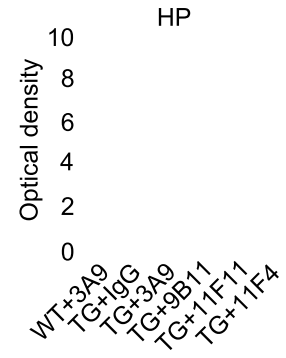

$J$

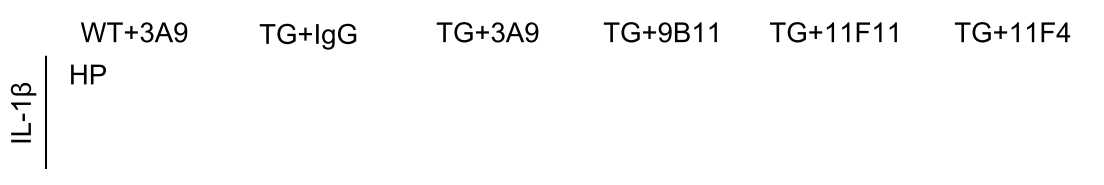

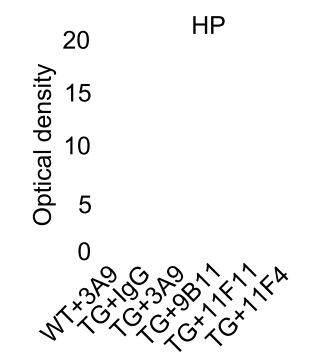

Fig. 4. Passive immunization reduces neurodegeneration, gliosis, and inflammation in mThy-1-a-synuclein Tg mice. (A) Representative images of mature neuron staining in the prefrontal cortex and hippocampus. (B, C) Optical density measurements in NeuN-immunopositive areas of the prefrontal cortex and hippocampus. (D) Representative images of astrogliosis staining in the parietal cortex and hippocampal regions. (E, F) Optical density measurements in GFAP-immunopositive areas of the parietal cortex and hippocampus. (G) Representative images of microgliosis staining in the prefrontal cortex and hippocampus. (H, I) Optical density measurements in Iba-1 immunopositive areas of the prefrontal cortex and hippocampus. (J) Representative images of IL-1 $\beta$ cytokine staining in the hippocampus. (K) Optical density measurements in IL-1 $\beta$ immunopositive areas of the hippocampus. Scale bar, $200 \mu \mathrm{m}(\mathrm{G})$ and $100 \mu \mathrm{m}(\mathrm{J})$. Data are expressed as means \pm s.e.m. $\left(\mathrm{n}=5 \sim 6\right.$ per group; $\# \mathrm{p}<0.05 \mathrm{vs}$. WT+3A9 group, ${ }^{*} \mathrm{p}<0.05 \mathrm{vs}$. TG+IgG group; one-way ANOVA with two-sided Tukey's post hoc test). Pfcx, prefrontal cortex; Pacx, parietal cortex; HP, hippocampus. 
not only by the rate of uptake but also by the rate of the intracellular degradation. Antibodies have shown to increase both uptake and degradation rates, hence increasing the overall clearance rate. Consistent with this, Gustafsson et al. [33] showed that mAb47, an antibody selective for oligomer/protofibril forms of $\alpha$-synuclein, enhanced the uptake of extracellular $\alpha$-synuclein via Fc $\gamma$ receptors. As for the role of antibodies in blocking cell-to-cell propagation, our present study reports that conformation-specific antibodies effectively decrease this process for $\alpha$-synuclein. These blocking effects have also been shown with antibodies against oligomers and fibrils of $\alpha$-synuclein by El-Agnaf and colleagues [34]. Taken together, our findings indicate that the mechanism of action of conformation-specific antibodies includes interference with cellto-cell propagation and increased clearance of $\alpha$-synuclein, actions akin to those of pan $\alpha$-synuclein antibodies.

Our results show that the efficacies of antibodies on microglial clearance and cell-to-cell propagation does not match. The biological effects of the antibodies are dictated not only by the affinity to the antigen but also by the interaction between the antibodies and specific cell types. Neurons and microglia express different repertoire of Fc receptors [35], which would result in cell type-specific responses to various antibodies. In the microglial clearance assay, 9B11 showed the strongest effect. The reason for this is not clear. However, the fact that $9 \mathrm{~B} 11$ is $\operatorname{IgG} 3$ while other conformationspecific antibodies tested are IgG2b might have influenced the efficiencies of these antibodies on the interaction with microglia. Unlike in microglia, the cell-to-cell propagation assay performed in a neuronal cell line showed a consistent result among the antibodies. The antibodies used in these tests have similar affinity to $a$-synuclein fibrils. Therefore, we speculate that the effects of antibodies on cell-to-cell propagation are determined mainly by the antibody-antigen affinity, whereas those on microglial clearance are determined by both antibody-antigen affinity and the antibody subtypes.

There is limited amount of direct evidence for cell-to-cell propagation in $\alpha$-synuclein tg mice. However, several PFF injection experiments have been performed in $\alpha$-synuclein tg models $[6,7$, 36-40]. These experiments clearly showed accelerated $\alpha$-synuclein aggregation in various brain regions, suggesting that cell-to-cell propagation of $\alpha$-synuclein probably occurs in the tg models. Another evidence for cell-to-cell propagation in a-synuclein tg model comes from the experiment where propagation blocker reduced a-synuclein pathology in a tg model. In this case, administration of anti-toll like receptor 2 (TLR2) antibody to an $\alpha$-synuclein $\operatorname{tg}$ mouse model significantly reduced the deposition of $a$-synuclein [41]. TLR2 has been shown to be a neuronal receptor mediating the cell-to-cell propagation of $a$-synuclein [41]. This effect of the propagation receptor strongly suggests that cell-to-cell propagation of $\alpha$-synuclein occurs in the transgenic mice.

In this study, conformation-specific antibodies were generated using both full-length and C-terminally truncated forms of a-synuclein fibrils. Among the antibodies generated, four showed high specificity for fibrils, three of which were raised from Cterminally truncated $\alpha$-synuclein fibrils, suggesting that immunization with C-terminally truncated $\alpha$-synuclein fibrils is more likely to generate conformation-specific antibodies. Using solidstate NMR together with electron microscopy and atomic force microscopy, it has been shown that the $\beta$-sheet-rich $\alpha$-synuclein fibril core corresponded to residues 38 98 [42, 43]. This core region is highly structured, whereas the $\mathrm{C}$-terminal region (residues 96 140) outside the core region is flexible and unfolded. Therefore, antibodies raised against the C-terminal region would not distinguish aggregates from monomers, probably explaining why immunization with C-terminally truncated $\alpha$-synuclein fibrils was more effective in generating aggregate conformation-specific antibodies.

A growing body of evidence supports the beneficial effects of passive immunization against $\alpha$-synuclein in animal models of synucleinopathy $[29,30,44-46]$. The more recent of these studies suggest that passive immunization with fibril- or protofibrilspecific antibodies is also effective in ameliorating disease phenotypes in animal models $[34,47,48]$. Our present study is the first to compare the efficacies of conformation-specific antibodies with those of a pan- $\alpha$-synuclein antibody. Our results demonstrate that the conformation-specific antibodies are as effective as a pan- $\alpha$ synuclein antibody in ameliorating the neuropathological features of a synucleinopathy model, including $\alpha$-synuclein aggregation, gliosis, neuroinflammation, and neuronal loss. This suggests that monomer recognition is not required for the success of passive immunization. The conformation-specific antibodies do not recognize the normal $\alpha$-synuclein, and thus would not interfere with the normal function of $a$-synuclein. Therefore, the use of conformation-specific antibodies that do not cross-react with monomers would have clear benefits in avoiding adverse effects of passive immunization by preserving the normal functions of monomeric $\alpha$-synuclein proteins. In conclusion, immunotherapy with conformation-specific antibodies raised against $\alpha$-synuclein fibrils could be effective in treating $\alpha$-synuclein-related diseases, such as $\mathrm{PD}$, without interfering with the normal functions of $\alpha$-synuclein proteins.

\section{ACKNOWLEDGEMENTS}

We are grateful to Eliezer Masliah (currently at NIA, Bethesda, 
MD, USA), Mike Mante and Jazmin Florio (Department of Neurosciences, School of Medicine, University of California San Diego, La Jolla, CA, USA) for the animal preparation. This work was supported by National Research Foundation (NRF) grants funded by the Korean Government (MEST) (NRF-2018R1A5A2025964, NRF-2021R1A2C3012681) and the Korea Healthcare Technology R\&D Project, Ministry of Health \& Welfare, Republic of Korea (HI19C0256). This work was also supported by ABL Bio, Inc. MC received a scholarship from the BK21-Plus education program.

\section{REFERENCES}

1. Dauer W, Przedborski S (2003) Parkinson's disease: mechanisms and models. Neuron 39:889-909.

2. Mehra S, Sahay S, Maji SK (2019) a-Synuclein misfolding and aggregation: implications in Parkinson's disease pathogenesis. Biochim Biophys Acta Proteins Proteom 1867:890-908.

3. Braak H, Ghebremedhin E, Rüb U, Bratzke H, Del Tredici K (2004) Stages in the development of Parkinson's diseaserelated pathology. Cell Tissue Res 318:121-134.

4. Braak H, Del Tredici K, Rüb U, de Vos RA, Jansen Steur EN, Braak E (2003) Staging of brain pathology related to sporadic Parkinson's disease. Neurobiol Aging 24:197-211.

5. Chu Y, Muller S, Tavares A, Barret O, Alagille D, Seibyl J, Tamagnan G, Marek K, Luk KC, Trojanowski JQ, Lee VMY, Kordower JH (2019) Intrastriatal alpha-synuclein fibrils in monkeys: spreading, imaging and neuropathological changes. Brain 142:3565-3579.

6. Luk KC, Kehm VM, Zhang B, O'Brien P, Trojanowski JQ, Lee VM (2012) Intracerebral inoculation of pathological a-synuclein initiates a rapidly progressive neurodegenerative a-synucleinopathy in mice. J Exp Med 209:975-986.

7. Paumier KL, Luk KC, Manfredsson FP, Kanaan NM, Lipton JW, Collier TJ, Steece-Collier K, Kemp CJ, Celano S, Schulz E, Sandoval IM, Fleming S, Dirr E, Polinski NK, Trojanowski JQ, Lee VM, Sortwell CE (2015) Intrastriatal injection of pre-formed mouse $a$-synuclein fibrils into rats triggers a-synuclein pathology and bilateral nigrostriatal degeneration. Neurobiol Dis 82:185-199.

8. Zhang B, Kehm V, Gathagan R, Leight SN, Trojanowski JQ, Lee VM, Luk KC (2019) Stereotaxic targeting of alphasynuclein pathology in mouse brain using preformed fibrils. Methods Mol Biol 1948:45-57.

9. Brundin P, Melki R (2017) Prying into the prion hypothesis for Parkinson's disease. J Neurosci 37:9808-9818.

10. Mezias C, Rey N, Brundin P, Raj A (2020) Neural connectivity predicts spreading of alpha-synuclein pathology in fibril- injected mouse models: involvement of retrograde and anterograde axonal propagation. Neurobiol Dis 134:104623.

11. Rey NL, Steiner JA, Maroof N, Luk KC, Madaj Z, Trojanowski JQ, Lee VM, Brundin P (2016) Widespread transneuronal propagation of $\alpha$-synucleinopathy triggered in olfactory bulb mimics prodromal Parkinson's disease. J Exp Med 213:17591778 .

12. Cookson MR (2005) The biochemistry of Parkinson's disease. Annu Rev Biochem 74:29-52.

13. Jang A, Lee HJ, Suk JE, Jung JW, Kim KP, Lee SJ (2010) Nonclassical exocytosis of alpha-synuclein is sensitive to folding states and promoted under stress conditions. J Neurochem 113:1263-1274.

14. Lee HJ, Patel S, Lee SJ (2005) Intravesicular localization and exocytosis of alpha-synuclein and its aggregates. J Neurosci 25:6016-6024.

15. Desplats P, Lee HJ, Bae EJ, Patrick C, Rockenstein E, Crews L, Spencer B, Masliah E, Lee SJ (2009) Inclusion formation and neuronal cell death through neuron-to-neuron transmission of alpha-synuclein. Proc Natl Acad Sci U S A 106:1301013015.

16. Lee SJ, Desplats P, Sigurdson C, Tsigelny I, Masliah E (2010) Cell-to-cell transmission of non-prion protein aggregates. Nat Rev Neurol 6:702-706.

17. Kim C, Ho DH, Suk JE, You S, Michael S, Kang J, Joong Lee S, Masliah E, Hwang D, Lee HJ, Lee SJ (2013) Neuron-released oligomeric $\alpha$-synuclein is an endogenous agonist of TLR2 for paracrine activation of microglia. Nat Commun 4:1562.

18. Lee HJ, Suk JE, Patrick C, Bae EJ, Cho JH, Rho S, Hwang D, Masliah E, Lee SJ (2010) Direct transfer of alpha-synuclein from neuron to astroglia causes inflammatory responses in synucleinopathies. J Biol Chem 285:9262-9272.

19. Hansson O, Hall S, Ohrfelt A, Zetterberg H, Blennow K, Minthon L, Nägga K, Londos E, Varghese S, Majbour NK, AlHayani A, El-Agnaf OM (2014) Levels of cerebrospinal fluid a-synuclein oligomers are increased in Parkinson's disease with dementia and dementia with Lewy bodies compared to Alzheimer's disease. Alzheimers Res Ther 6:25.

20. Park MJ, Cheon SM, Bae HR, Kim SH, Kim JW (2011) Elevated levels of $\alpha$-synuclein oligomer in the cerebrospinal fluid of drug-naïve patients with Parkinson's disease. J Clin Neurol 7:215-222.

21. Tokuda T, Salem SA, Allsop D, Mizuno T, Nakagawa M, Qureshi MM, Locascio JJ, Schlossmacher MG, El-Agnaf OM (2006) Decreased alpha-synuclein in cerebrospinal fluid of aged individuals and subjects with Parkinson's disease. Biochem Biophys Res Commun 349:162-166. 
22. Lee HJ, Bae EJ, Lee SJ (2014) Extracellular $\alpha$--synuclein-a novel and crucial factor in Lewy body diseases. Nat Rev Neurol 10:92-98.

23. Bae EJ, Yang NY, Song M, Lee CS, Lee JS, Jung BC, Lee HJ, Kim S, Masliah E, Sardi SP, Lee SJ (2014) Glucocerebrosidase depletion enhances cell-to-cell transmission of a-synuclein. Nat Commun 5:4755.

24. Lee HJ, Choi C, Lee SJ (2002) Membrane-bound alpha-synuclein has a high aggregation propensity and the ability to seed the aggregation of the cytosolic form. J Biol Chem 277:671678.

25. Rockenstein E, Mallory M, Hashimoto M, Song D, Shults CW, Lang I, Masliah E (2002) Differential neuropathological alterations in transgenic mice expressing alpha-synuclein from the platelet-derived growth factor and Thy-1 promoters. J Neurosci Res 68:568-578.

26. Kim TK, Lee JE, Kim JE, Park JY, Choi J, Kim H, Lee EH, Han PL (2016) G9a-mediated regulation of OXT and AVP expression in the basolateral amygdala mediates stress-induced lasting behavioral depression and its reversal by exercise. Mol Neurobiol 53:2843-2856.

27. Lee HJ, Suk JE, Bae EJ, Lee JH, Paik SR, Lee SJ (2008) Assembly-dependent endocytosis and clearance of extracellular alpha-synuclein. Int J Biochem Cell Biol 40:1835-1849.

28. Lee HJ, Suk JE, Bae EJ, Lee SJ (2008) Clearance and deposition of extracellular alpha-synuclein aggregates in microglia. Biochem Biophys Res Commun 372:423-428.

29. Bae EJ, Lee HJ, Rockenstein E, Ho DH, Park EB, Yang NY, Desplats P, Masliah E, Lee SJ (2012) Antibody-aided clearance of extracellular $\alpha$-synuclein prevents cell-to-cell aggregate transmission. J Neurosci 32:13454-13469.

30. Tran HT, Chung CH, Iba M, Zhang B, Trojanowski JQ, Luk KC, Lee VM (2014) A-synuclein immunotherapy blocks uptake and templated propagation of misfolded $\alpha$-synuclein and neurodegeneration. Cell Rep 7:2054-2065.

31. Paleologou KE, Kragh CL, Mann DM, Salem SA, Al-Shami R, Allsop D, Hassan AH, Jensen PH, El-Agnaf OM (2009) Detection of elevated levels of soluble alpha-synuclein oligomers in post-mortem brain extracts from patients with dementia with Lewy bodies. Brain 132(Pt 4):1093-1101.

32. Chesselet MF, Richter F, Zhu C, Magen I, Watson MB, Subramaniam SR (2012) A progressive mouse model of Parkinson's disease: the Thy1-aSyn ("Line 61") mice. Neurotherapeutics 9:297-314.

33. Gustafsson G, Eriksson F, Möller C, da Fonseca TL, Outeiro TF, Lannfelt L, Bergström J, Ingelsson M (2017) Cellular uptake of $\alpha$-synuclein oligomer-selective antibodies is enhanced by the extracellular presence of $a$-synuclein and mediated via Fc $\gamma$ receptors. Cell Mol Neurobiol 37:121-131.

34. El-Agnaf O, Overk C, Rockenstein E, Mante M, Florio J, Adame A, Vaikath N, Majbour N, Lee SJ, Kim C, Masliah E, Rissman RA (2017) Differential effects of immunotherapy with antibodies targeting $\alpha$-synuclein oligomers and fibrils in a transgenic model of synucleinopathy. Neurobiol Dis 104:85-96.

35. Katsinelos T, Tuck BJ, Mukadam AS, McEwan WA (2019) The role of antibodies and their receptors in protection against ordered protein assembly in neurodegeneration. Front Immunol 10:1139.

36. Mougenot AL, Nicot S, Bencsik A, Morignat E, Verchère J, Lakhdar L, Legastelois S, Baron T (2012) Prion-like acceleration of a synucleinopathy in a transgenic mouse model. Neurobiol Aging 33:2225-2228.

37. Sacino AN, Brooks M, Thomas MA, McKinney AB, Lee S, Regenhardt RW, McGarvey NH, Ayers JI, Notterpek L, Borchelt DR, Golde TE, Giasson BI (2014) Intramuscular injection of a-synuclein induces CNS $a$-synuclein pathology and a rapidonset motor phenotype in transgenic mice. Proc Natl Acad Sci U S A 111:10732-10737.

38. Flores-Cuadrado A, Saiz-Sanchez D, Mohedano-Moriano A, Martinez-Marcos A, Ubeda-Bañon I (2019) Neurodegeneration and contralateral $\alpha$-synuclein induction after intracerebral a-synuclein injections in the anterior olfactory nucleus of a Parkinson's disease A53T mouse model. Acta Neuropathol Commun 7:56.

39. Schaser AJ, Stackhouse TL, Weston LJ, Kerstein PC, Osterberg VR, López CS, Dickson DW, Luk KC, Meshul CK, Woltjer RL, Unni VK (2020) Trans-synaptic and retrograde axonal spread of Lewy pathology following pre-formed fibril injection in an in vivo A53T alpha-synuclein mouse model of synucleinopathy. Acta Neuropathol Commun 8:150.

40. La Vitola P, Balducci C, Baroni M, Artioli L, Santamaria G, Castiglioni M, Cerovic M, Colombo L, Caldinelli L, Pollegioni L, Forloni G (2021) Peripheral inflammation exacerbates $\alpha$-synuclein toxicity and neuropathology in Parkinson's models. Neuropathol Appl Neurobiol 47:43-60.

41. Kim C, Spencer B, Rockenstein E, Yamakado H, Mante M, Adame A, Fields JA, Masliah D, Iba M, Lee HJ, Rissman RA, Lee SJ, Masliah E (2018) Immunotherapy targeting toll-like receptor 2 alleviates neurodegeneration in models of synucleinopathy by modulating a-synuclein transmission and neuroinflammation. Mol Neurodegener 13:43.

42. Chen M, Margittai M, Chen J, Langen R (2007) Investigation of alpha-synuclein fibril structure by site-directed spin label- 
ing. J Biol Chem 282:24970-24979.

43. Heise H, Hoyer W, Becker S, Andronesi OC, Riedel D, Baldus M (2005) Molecular-level secondary structure, polymorphism, and dynamics of full-length alpha-synuclein fibrils studied by solid-state NMR. Proc Natl Acad Sci U S A 102:15871-15876.

44. Masliah E, Rockenstein E, Mante M, Crews L, Spencer B, Adame A, Patrick C, Trejo M, Ubhi K, Rohn TT, MuellerSteiner S, Seubert P, Barbour R, McConlogue L, Buttini M, Games D, Schenk D (2011) Passive immunization reduces behavioral and neuropathological deficits in an alphasynuclein transgenic model of Lewy body disease. PLoS One 6:e19338.

45. Games D, Valera E, Spencer B, Rockenstein E, Mante M, Adame A, Patrick C, Ubhi K, Nuber S, Sacayon P, Zago W, Seubert P, Barbour R, Schenk D, Masliah E (2014) Reducing C-terminal-truncated alpha-synuclein by immunotherapy attenuates neurodegeneration and propagation in Parkinson's disease-like models. J Neurosci 34:9441-9454.
46. Spencer B, Valera E, Rockenstein E, Overk C, Mante M, Adame A, Zago W, Seubert P, Barbour R, Schenk D, Games D, Rissman RA, Masliah E (2017) Anti- $\alpha$-synuclein immunotherapy reduces $\alpha$-synuclein propagation in the axon and degeneration in a combined viral vector and transgenic model of synucleinopathy. Acta Neuropathol 5:7.

47. Henderson MX, Covell DJ, Chung CH, Pitkin RM, Sandler RM, Decker SC, Riddle DM, Zhang B, Gathagan RJ, James MJ, Trojanowski JQ, Brunden KR, Lee VMY, Luk KC (2020) Characterization of novel conformation-selective $\alpha$-synuclein antibodies as potential immunotherapeutic agents for Parkinson's disease. Neurobiol Dis 136:104712.

48. Lindström V, Fagerqvist T, Nordström E, Eriksson F, Lord A, Tucker S, Andersson J, Johannesson M, Schell H, Kahle PJ, Möller C, Gellerfors P, Bergström J, Lannfelt L, Ingelsson M (2014) Immunotherapy targeting $\alpha$-synuclein protofibrils reduced pathology in (Thy-1)-h[A30P] a-synuclein mice. Neurobiol Dis 69:134-143. 